\title{
Studies into the Folk Hagiography of the Russian North:Judas Koneschelsky
}

\author{
Andrey B. Moroz \\ School of Philology at the National Research University Higher School of \\ Economics; Institute of Phylology and History at the Russian State \\ University for the Humanities, Moscow, Russia \\ abmoroz@yandex.ru \\ Alexander V. Pigin \\ Institute of Linguistics, History and Literature, Karelian Research Centre of \\ RAs, Petrozavodsk, Russia \\ av-pigin@yandex.ru
}

\begin{abstract}
The article deals with the problems of studying folk hagiography, a complex of peasants' written and oral texts, which contain information about saints or revered non-canonized devotees and express the very specifics of the popular understanding of holiness. The first half of the article discusses the phenomenon of folk hagiography, defines the range of folklore genres, reflecting folk beliefs about saints, and investigates the mechanisms of interaction between the written and oral traditions. The second half analyzes texts and religious practices related to the folk worship of the non-canonized elder Judas Koneschelsky (Archangelsk North). There are following sources for the study of this cult: judicial documents of the turn of the 19th and the 2oth centuries, a peasant's diary of the turn of the 19th and the 2oth centuries, local priests' notes from that time, and field data, collected by folklorists at the beginning of the 21th century. On the basis of these sources, the authors, considering a specific case, make an attempt to study the mechanisms of functioning of folk hagiography. A large time span between the early and late data records and various texts about Judas make it possible to trace evolution of this cult.
\end{abstract}

\section{Keywords}

folk hagiography - veneration of saints - Judas Koneschelsky 
In anthropology and folklore studies, it has already become the norm to speak about folk or popular religion (or religiosity).* Researchers always implies some opposition to the so-called official religion (religiosity). However, relatively recently some attempts were made to revise this view. In 1995, Leonard Primiano was the first to reconsider the dichotomy between the 'official' and 'unofficial'. He drew attention to the fact that religion, belonging to the sphere of perception, consciousness, and culture of specific people, always exists only in the form conceived by a particular person; and, strictly speaking, no one, including the Pope, the Ecumenical Patriarch, or the Dalai Lama, can be the bearer of "the official religion". Instead of using the concept of folk or popular religion, the author suggests applying the concept of vernacular religion, implying by it those forms of religion that are embodied in the beliefs and practices of any person. «Vernacular religionis, by definition, religion as it is lived: as human beings encounter, understand, interpret, and practice it. Since religion inherently involves interpretation, it is impossible for the religion of an individual not to be vernacular. Vernacular religious theory involves an interdisciplinary approach to the study of the religious lives of individuals with special attention to the process of religious belief, the verbal, behavioral, and material expressions of religious belief, and the ultimate object of religious belief». ${ }^{2}$ Thus, vernacular religion is opposed to institutional religion.

A. Panchenko thinks similarly, noting that the approach contrasting the "official" religion with the "popular" one is "directly determined by the claims of social elites who usurp the right to control society in the sphere of religious life. It is the elites who construct the very image of the "popular religion", defining the latter according to the apophatic, "negative" principle, as something that does not correspond to the postulated religious norm. [...] However, in reality this is not true: both in synchronic and diachronic terms, the "institutional" religion varies and depends on a wide variety of social processes and phenomena. Moreover, from the practical point of view, the norm is always illusory, because in reality it usually represents an object of conflicting interpretations". ${ }^{3}$

* The study was funded by the Russian Foundation for Basic Research (project № 17-24-01004) (A. Moroz) and carried out under state order (project No AAAA-A18-118030190094-6) (A. Pigin). Translated from Russian into English by Serge V. Orlov Petrozavodsk State Glazunov Conservatory).

1 L.N. Primiano, "Vernacular Religion and the Search for Method in Religious Folklife", in: Western Folklore, vol. 54 (1995), pp. 37-56.

2 L.N. Primiano, "Vernacular Religion", p. 44.

3 А.А. Панченко, Иван и Яков - необычные святые из болотистой местности: «Крестьянская агиология» и религиозные практики в России Нового времени [А.A. Panchenko, 
At the same time, giving credit for fair criticism of the old conventional designations, L. Primiano's dichotomy does not always accurately reflect the specifics of the material. There is a necessity for its more fractional division into types, in particular, on the basis of belonging to a certain social environment. Traditionally and currently utilized in academic discourse notations popular and folk cause many objections, yet possess sufficient transparency. Primarily, they are supposed to be related to the peasant culture. Taking into consideration the agrarian nature of the Russian economy before the second quarter of the 2oth century and a relative isolation of the peasant environment right up to the middle of the 2oth century, this relation to the peasant culture is necessary in order to understand in what kind of society the religious texts and practices, observed in this study, have been formed, recorded, and functioned. So the adjective folk pertains here to the peasant culture, which is oral at its core, but does not exclude, however, the essential role of written texts.

The term hagiography also needs to be clarified. The texts, comprising folk hagiography, can be divided into two unequal groups. The first one are texts, generated from time to time among the worshippers of non-canonized elders describing their miracles. ${ }^{4}$ Such folk hagiographies emerge in the areas of veneration of the elders, among their contemporaries and acquaintances, or among those who contribute to the cult formation. The model for these texts is the literary hagiographic tradition (the lives of the saints), where they borrow compositional features, plot techniques, stylistic devices, and language particularities, i.e. attempts to use the Old Church Slavonic language or at least some of its expressions. On one hand, we evidence the authors' lack of experience in creating texts that would comply with Old Church Slavonic grammar and stylistics; on the other, we notice the authors' good knowledge of the local cult, presence of numerous everyday details, names, and designations, all of which build a sense of authenticity and immersion in the described events.

The second group is much larger and consists of folk oral texts, known to almost all members of society, which is far more numerous than the worshippers' circles of non-canonized elders. As a matter of fact, the characters of these texts are usually widely revered saints, who have been glorified for a long time, as the oral tradition forms slowly.

Ivan and Jacob are Unusual Saints from the Marshland: "Peasant Hagiography" and Religious Practices in Russia of the New Age"], Moscow, 2012, pp. 5-6.

4 Seе: Старец-мирянин ХХ века Федор Степанович Соколов, подготовка текста к изданию Г.М. Прохорова. [Secular Elder of the 2oth Century Feodor Michailovich Sokolov, ed. by G.M. Prokhorov]. St. Petersburg, 2002; О.А. Черепанова, Культурная память в древнем и новом слове [O.A. Cherepanova, Cultural Memory in Ancient and New Word]. St. Petersburg, 2005, pp. 269-293, etc. 
This group includes a complex of folklore and ritual practices, which, to some degree, explicitly or implicitly, contain information about saints and demonstrate the specifics of peasants' knowledge about them, as well as the very understanding of holiness and logic, underlying the perception of another person (departed or alive) as a saint. In the case of folk veneration of a saint or popular knowledge of him, to speak about a single type of texts, expressing this knowledge, is not possible, since it is reflected in numerous texts of heterogeneous nature and practices of worshiping saints (no matter officially recognized or not).

Folklore texts, which contain information about saints and reflect their cult, belong to different genres and are usually studied separately as a part of group, belonging to a particular genre. ${ }^{5}$ Indeed, one would ask: what is common between Christian legends, even in the broadest sense of this genre, as a narrative of religious content, a story about a visit to a holy well, and a folk saying? In terms of genre - nothing, meanwhile, if the name of a saint is mentioned in all three types of texts, they turn out to be connected to the same system, maintaining popular beliefs about saints and veneration. In this respect, the calendar paroemia that the Prophet Elijah "stole two hours", a taboo against working on Elijah's day so that lightning doesn't set fire to haystacks, veneration of Elijah's springs, a popular belief that lightning is arrows, which the Prophet, riding a chariot across the sky, shoots at the Devil, and a legend about the stern Elijah, who wants to punish a man for lack of piety, and the good Nicholas, who saves the peasant from the terrible saint's wrath ${ }^{6}$, constitute a single unit of data about the saint, inducing various forms of his cult. It is the connection of these texts with the veneration of saints that puts them together in a special group.

Thus, folk hagiographic texts are an aggregate of various genres, which, to a greater or lesser extent, reflect peasants' knowledge of saints and holiness. This type, besides hand-written texts about life and miracles, encompasses oral legends, paroemiac texts (proverbs and sayings), especially, texts of paroemiac character, associated with calendar dates - holidays commemorating saints (proverbs, sayings, calendar related sayings), sacred verses, calendar songs mentioning saints or holidays in their honor, spells, and prayers.

Another important genre for folk hagiography is texts that are referred to as popular beliefs in modern Russian folklore studies. They designate "a verbally

5 See, for example: Ю.М. Шеваренкова, Исследования в области русской фольклорной легенды [Yu. M. Shevarenkova, Studies into Russian Folklore Legend]. Nizhny Novgorod, 2004.

6 А.Н. Афанасьев, Народные русские легенды [A.N. Afanas'ev, Russian Folk Legends]. London, 1859, pp. 39-42, № 10. 
presented demonological notion". 7 The basic difference between demonological representations and belief narratives is absence of a plot. Thus, the supernatural belief communicates information of a general type, not applying it to specific situations, characters, time and place, and explains who the demonological characters are, what a human should or shouldn't do in order not to incur their wrath, and what are the taboos and prescriptions. ${ }^{8}$ As a matter of fact, this definition shouldn't be confined to demonological characters and could be extended to the whole realm of the unearthly and otherworldly, since all supernatural characters demand special treatment and adherence to etiquette standards. In this respect the differences between demonological and sacral characters are minimal and determined mainly by the literary origin of information about the latter. To sum up, beliefs - plotless narrations about who the particular saints are (specifically, responses to straightly asked questions, such as who is saint $\mathrm{x}$, how and why should he be worshipped, etc.), what makes them strong and how to venerate them, also belong to folk hagiographic texts.

Folk hagiography corpus could also include several categories of texts that generally remain outside researchers' fields of interest. These are folk-etymological interpretations of saints' names, calendar holidays, descriptions of icons, retellings of saints' lives, etc. M. Detelich notes, that with a small number of folklore genres and their rigid framework, storylines and images coming from books (written texts), actively occupy intermediate, inter-genre areas, which she calls folklore "grey areas". 9

The influence of literature on the traditional culture is very noticeable: written texts, primarily those that are perceived as sacred (the Holy Scriptures, the Apocrypha, hagiographies, and prayers) are orally retold and finally transformed into folklore texts, which are reproduced, as is characteristic of folklore, in certain typical situations. Retellings of literary texts, done by the bearers of traditional culture, become a part of this culture and start living by the laws of the folklore oral narrative. In this case, we often deal not with retellings of primary sources, but with retellings of what has been retold once or even twice, etc. Such authoritative sources of information as priests, teachers, and in the

Л.Н. Виноградова, “Былички и демонологические поверья: границы фольклорного текста" [L.N. Vinogradova, "Belief narratives and Demonological representations : Boundaries of Folklore texts"], in: Живая старина [The Living Antiquity], (2004), Nr 1, pp. 10-14.

8 Л.Н. Виноградова, “Былички и демонологические поверья”, р. 13.

9 М. Детелић, "Света Петка у сивој зони усмене књижевности" [M. Detelich, "Saint Paraskevi in the Grey Zone of Oral Literature"], in: Лищеум [Lyceum]. Kragujevac (2001), vol. 5, pp. 123-135. 
modern world also radio, television and the press can act as intermediary elements. The information, gathered from these sources, is not subjected to critical assessment, but perceived as a priori reliable. This, however, doesn't save them from unwitting distortion and adjustment of content and form to folklore stereotypes..$^{10}$ Retellings of hagiographic texts constantly contribute to the corpus of legends, serving as the main source of hagiographic data. However, it doesn't usually happen that the retelling of a written hagiography becomes a legend; a lot of retellings are just incorporated into everyday speech and characteristics depend on the communicative situation. Research into these marginal texts reveals significant aspects of the popular veneration of saints and displays some key factors in its formation.

When hagiographies are being retold, a selection of episodes always occurs - the whole hagiography is never retold. Each separate retelling usually contains from one to three episodes, often communicated as a cumulative chain (which, by the way, is also typical for describing saints' miracles in hagiographies). These episodes strike a chord with the folklore mind ${ }^{11}$ and are selected according to specific requirements: vividness, correlation with the forms of traditional life, attachment to a specific time and/or place, etc. However, the whole range of such episodes is much narrower than in a hagiography and counts, as a rule, from 3 to 5 most significant, from the folklore tradition perspective (and, quite possibly, quite minor from the hagiography perspective) facts borrowed from the miracles, which a saint performed during his lifetime. Often these miracles are related to folk beliefs, which don't have direct links with the cult of saints. Thus, magic stones, springs, and trees are widely

See: M.M. Каспина, “Феномен смешения различных традиций, возникающий при пересказах информантами библейских сюжетов" [M.M. Kaspina, "The Phenomenon

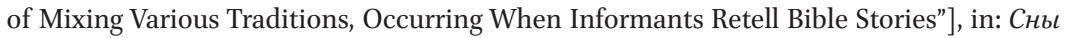
Богородицы. Исследования по антропологии религии, редакторы Ж.В. Кормина, А.А. Панченко, С.А. Штырков [Theotokos's Dreams. Studies into the Anthropology of Religion, ed. by Zh. V. Kormina, A.A. Panchenko, S.A. Shtyrkov]. St. Petersburg, 2006, pp. 226-243; А.Б. Мороз, “О фольклорности нефольклорного (евангельские события в восприятии современного крестьянина)" [А.B. Moroz, "On the Folklore Nature of Non-Folklore Matter (Gospel Events in the Perception of the Modern Peasant")], in: Актуальные проблемы полевой больклористики, редактор А.А. Иванова [Topical Issues of Fieldwork Studies on Folklore, ed. by A.A. Ivanova]. Moscow, 2002, [iss. 1], pp. 31-43; Л.В. Фадеева, "Книга как источник народного жития святого праведного Иоанна Кронштадтского" [L.V. Fadeeva, "The Book as a Source of Folk Hagiography of the Holy Righteous John of Kronstadt"], in: Актуальные проблемы полевой фольклористики, редактор А.А. Иванова [Topical Issues of Fieldwork Studies on Folklore, ed. by A.A. Ivanova]. Moscow, 2002, [iss. 1], pp. 43-53.

11 W. Telfer, "The Cultus of St. Gregory Thaumaturgus", The Harvard Theological Review, 29 (1936), pp. 325-344. 
venerated outside the cult of saints, however, they can get connected later with saints and become sacred due to the intervention of a saint. In places where a particular saint is worshipped (for example, in a settlement where he was born or in the vicinity of the monastery that he founded) there is a tendency to explain any extraordinary phenomenon or even a local toponym by the activities of a definite saint. Moreover, he takes over the functions traditionally attributed to other widely revered saints (George, Nicholas, Pantaleon). The miracles performed by saints are interpreted in accordance with the popular notions of magic; a saint is often described in terms that are widely applied to sorcerers and healers, which reflects a certain similarity between these characters in the folklore consciousness. The names of saints and their holidays, their images on icons are also interpreted in a similar way.

Thus, we encounter a kind of "hypertext" based on two traditions - the "literary" one and folklore. The "literary tradition" comprises not only literary sources (hagiographies, akathist hymns, euchologies, etc.), but also iconic images, since when painting an icon, the text of a hagiography usually serves as the basis for creating a saint's image". 12

Since informants, when retelling hagiographies, describing personal religious experiences or interpreting iconic images (consciously or not), follow more traditional texts of legends, one can claim, these narratives possess a certain uniformity and stability of the structure.

When considering the correlation between literary and folklore texts of hagiographic nature, an important question inevitably arises: what comes first? Does the literary hagiographic text underlie folk legends and the whole concept of a saint, or, conversely, it is the hagiography that is based on oral legends and stories. This question has been crucial for quite a long time, and many well-known researchers of hagiography have raised it. Among goals that researchers of hagiographies often set is to determine to what extent the hagiographer used traditional hagiographic clichés, to what extent he relied on folklore or "monastic" legend, and, finally, to what extent he was guided by real historical facts. However, if hagiographic clichés, moving from one Life of a saint to another, are easy to single out and the accuracy of historical events can

12 А.А. Иванова, “«Устное житие» Артемия Веркольского (по материалам экспедиций в Пинежский район Архангельской области)" [А.A. Ivanova, "Oral Hagiography" of Artemy Verkolsky (based on expedition materials to Pinezhsky region of Archangelsk region)"], in: Актуальные проблемы полевой фольклористики, редактор А.А. Иванова [Topical Issues of Fieldwork Studies on Folklore, ed. by A.A. Ivanova], Syktyvkar, 2008, iss. 4, pp. 170-179; А.И. Рыко, “Литературный текст в традиционном бытовании (“Сказка о царе Салтане” в Новгородской области)" [A.I. Ryko, "Literary text in the Traditional usage (The Tale of Tsar Saltan in Novgorod province)"], in: Slověne 6 (2017), Nr 1, pp. 518-539. 
be verified by other sources, we can hardly be sure that we deal with a folk legend in this case.

Meanwhile, it takes a long time for a legend to become a hagiography. The oral text often undergoes tremendous changes. Moreover, this oral source may not exist. No doubt, before the canonization, relics have been examined, eyewitnesses have been questioned about the miracles, and their stories, later forming the basis of the hagiography, have been recorded. However, is it right to define such accounts as legends or tales and relate them to oral culture without seeing the actual text?

Studies into the oral tradition in areas, where certain saints are particularly venerated, have proved that the correlation between literary and oral texts can be diverse. They can exist in parallel, completely independent from each other. For instance, legends about St. Alexander Oshevensky, widely spread in the village of Oshevensk, where the saint founded a monastery and got famous, and in neighboring villages, have nothing in common with the Hagiography of St. Alexander. Nevertheless, in most cases, there is influence of some texts on others. Along with utilizing oral legends in written hagiographies, the opposite phenomenon is also widespread. Hagiographies have been readily read and listened to by peasants in the 19th century. Nowadays they are still being read. Information, gathered from printed sources, is retold, gradually acquiring the form of folklore narrative.

Adapting literary text to the folk consciousness means "translating" it into the language of traditional culture. This mechanism could be described something like this: information obtained from an "external", non-traditional source becomes the subject of oral transmission. At the same time, everything extraneous, which cannot be explained by the mechanisms of traditional culture, is eliminated; the plot is modified. To communicate the plot, the speaker uses familiar and traditional concepts, but gives an account of events in his/her own way. Thus, consciously or not, the stated facts are interpreted, which makes it possible to claim that we are dealing here with some kind of "folk hermeneutics". The features of this "translation" vividly reflect the specifics of the folk cult of saints. In addition, retellings of literary texts never completely depend on their originals. They are greatly simplified, since multi-episode structures and developed plotlines are not typical for folklore narratives.

Probably, due to the fact that the recounted events are of a sacral nature and their significance is felt at the moment of speaking, the situation is subject not only to interpretation, but also to an emotional assessment. In the course of the narration the spatial, temporal, psychological, and other distances between recounted events and the moment of retelling shrink. The events are set in modern times or resent past and nearby place. They are provided with 
present-day motivations, allowing them to be included into the current system of values. The facts, recounted in such a way, do not exist separately; the speaker tries to encompass them with similar (in terms of the plotline, characters, situations, atmosphere, etc.) phenomena, establishing causal and other types of relationships between events of different nature. Even in cases when a certain text is being retold, the speaker tends to include facts of similar content, which he knows from other sources. This is how he/she fills lacunae and explains details which are not clear enough.

Saints form a special category of characters in various folklore genres and folklore mythology. Even in cases when a saint is mistaken for an ordinary person and portrayed as a human, in truth, it turns out to be only a deceptive appearance, and further recognition follows (ATU $75^{0-753, ~} 77^{13}$ et al). In actual beliefs, as well as in legends, saints are rarely perceived as ordinary people, even though they have deserved God's grace, they are initially credited with exceptional and magical properties. Therefore, folk hagiography focuses on describing miracles, ignoring the fact that hagiographies should serve as a model for exemplary behavior. Yet, in case a saint is perceived as a human, and the reason why he has achieved holiness is stated, this reason is usually his earthly life and relationships with people.

The folk cult of saints does not require from the bearers of the tradition any adequate biographical knowledge of the saint; often the knowledge the bearers possess is only the saint's name. Regarding a significant number of saints, revered everywhere, the majority of informants know nothing at all except the fact that each saint is associated with a specific function and expectation (St George protects cattle, St Pantaleon heals, St Elijah brings a thunderstorm and punishes those who work on St Elijah's day, etc.). In other cases, when a certain saint is for some reasons especially venerated, this veneration is usually based on a single fact or attribute, which emerges or is updated due to the existence of a church, monastery or chapel, consecrated in his honor, a shrine in rural landscape, related to him, or real biographical facts. The bearers of the tradition explain to themselves and outsiders an exceptional veneration of a certain saint in a certain area by mainly stating that he is one of the locals, i.e. his holiness has been especially manifested in the particular area, and he has singled out this place from the other ones by his doings.

The approaches to assimilate saint could be the attraction of toponyms (a saint associated with a certain place turns out to be one of the locals in another of the same name) or a fictitious statement of his stay in a particular

13 Aarne-Thompson-Uther Classification of Folk Tales. URL: <http://www.mftd.org/index. php?action=atu $>$. 
area. In all cases the properties of the protector and helper are attributed to saints. Another approach is to interpret a hagiography, iconography and even a saint's name in terms of the current needs of society. The hagiography of St. Modestus of Jerusalem narrates how he healed cattle, so he turns out to be Medosius, the patron saint of cattle in the Northern Russian tradition; St. Cosmas (Kuzma) through paronymic attraction with the verb "to forge" (kovat') turns out to be a blacksmith, interestingly enough, this craft has a very broad meaning: Kuzma binds everything that needs to be connected, including wedded couples or sodden roads (on the saints' day, November 1 frost is expected, which will make dirt roads solid). At the local level, within the boundaries of a small area, veneration of a saint as a patron of a locality may be because a temple or chapel bears his name or there is a sacred locus. As a result, legends emerge, motivating his relationship with a particular local group.

In certain territories, usually associated with the life of Christian devotees, their cult has a specific character. They are acutely perceived as the locals, "our" saints, in such zones the saint's literary hagiography or its folklore version is rather well known and they fully superimpose onto the landscape. The origin and magic properties of various objects are attributed to the ascetic's activities. He takes over the functions of other saints and even God. As a rule, the cult of such saints is confined to a specific area and is of local nature.

The second part of the paper analyzes texts and religious practices, related to the folk veneration of the non-canonized elder Judas Koneschelsky, who worked in Mezen, Leshukon'ye (Archangelsk North). Based on this material we'll make an attempt to trace some mechanisms of folk hagiography functioning.

The information about Judas' veneration is extracted from archival materials of the turn of the 18th-19th centuries, records of his miracles in the 19th century, the diary of the Mezen peasant G. Ya. Sitnikov, ${ }^{14}$ some sources of the 1910s-1920s (materials of the priest A. Grivtsev ${ }^{15}$ and the folklorist A.N. Nikiforov ${ }^{16}$ ), it is also contained in the field data, collected in expeditions by

14 Seе: А.В. Пигин, "Крестьянские дневники XIX-XX вв. как источники по изучению народной культуры (дневник Г.Я. Ситникова)" [A.V. Pigin, "Peasants' Diaries of the 19th-2oth Centuries as Sources for the Study of Folk Culture (G. Ya. Sitnikov's Diary”], in: Кижский вестник, научн. ред. А.В. Пигин и И.В. Мельников [Kizhi Annals, ed. by A.V. Pigin, I.V. Mel'nikov]. Petrozavodsk, 2017, iss. 17, pp. 278-285.

А. Гривцев,“Белощельский приход Мезенского уезда” [A. Grivtsev, “Beloshchel'ye Parish of Mezen District"], in: Архангельские епархиальные ведомости [Archangelsk Diocesan Bulletin], 1911, Nr 2, pp. 63-67. 
the Russian State University for the Humanities (Moscow) in the village of Vozhgora (2014) and Saint Petersburg State University in the villages of Vozhgora, Tsenogora, Selishche, and Beloshchel'ye (2009-2010, 2016 г.) ${ }_{1}^{17}$ in recent local lore literature, as well as in notes and essays (newspaper, online publications, etc.) written by local residents, pilgrims and tourists. The materials at our disposal cover a wide time span, enabling to trace the evolution in veneration practice of the Mezen elder.

Genuine historical facts about Judas Koneschelsky, called by the locals Judas (Uda) Trophimovich (or Tropinich) ${ }^{18}$, haven't survived. In 1799-180o two Mezen courts (District and County) heard the case of peasants from the village of Beloshchel'ye, who were accused of "false revelation" concerning Judas's sanctity $^{19}$. According to the case files, Judas used to live for some time in the hut he had built in the forest on the Popyuga river (the Mezen river tributary) and he died there. Yakov Mironov Novikov, a peasant from the village of Beloshchel'ye, found his body and buried him; it had happened long before the trial, as Ya. M. Novikov died in 1761. Later (the exact date in the documents is missing) Ya. M. Novikov's son Trofim together with Judas's stepson Felix and peasant Ivan Sofronov buried in the same spot a fallen horse, which, either in a vision or in reality, turned into Judas Trofimovich. Around 1792, Trofim, after receiving healing at Judas's grave, built there a chapel-barn, where pilgrims started to come and put their money and belongings. Based on the interrogation of peasants from Koynas district the Mezen County Court found that Judas had been a peasant, Old Believer from the Ostashyev family in Beloshchel'ye. After a prolonged hearing of the case, the court ruled that Trofim Novikov, Feklist and Ivan Sofronov should be severely punished - get flogged. The barn, built over Judas's body, was to be destroyed, and the items, stored there, were to be taken to the church of the Koynas parish. According to censuses, the Ostashyevs did

на Русский Север 1926-1928 г2., вступ. ст., сост., подгот. текстов и коммент. М.Н. Власовой [Fairy Tales. Legends. Bailichkas. Children's Folklore. Unpublished materials from expeditions to the Russian North 1926-1928, foreword, compilation, edition and comments by M.N. Vlasova]. St. Petersburg, 2018, pp. 594-595.

17 About the expedition to Beloshchel'ye by Saint Petersburg State University in 2016 see: А. Балакин, А. Поспелова, “Поездка к святым местам Помезенья” [A. Balakin, A. Pospelova, "Trip to the Holy Sites of Mezen Land"], in: Соловеикое море: Историко-литературный альманах, под ред. В. Матонина [The Solovki Sea: Historical and Literary Almanac, ed. by V. Matonin]. Arkhangelsk, 2016, Nr 15, pp. 168-174.

18 The nickname "Tropinich" was recorded by A.I. Nikiforov in 1920s, however, it is not found in other sources (Сказки. Легенды. Былички. Детский больклор, p. 594).

19 These documents, housed in the State Archives of Archangelsk District, have been published and commented in: А.В. Новиков, Ущельский монастырь (история обители в документах) [A.V. Novikov, The Monastery of Ushchel'ye (history of the monastery recorded in documents) ]. Arkhangelsk, 2018, pp. 156-172. 
reside in the village of Beloshchel'ye in the 18 th century, ${ }^{20}$ however, the name of Judas Trofimovich Ostashyev is not present in these documents.

Gradually, in Mezen region it was completely forgotten that Judas Koneschelsky had originated from the local peasant milieu of the Old Believers. Nevertheless, people continued to venerate him; celebration of Judas fell on June 19, commemoration day of Jude the Apostle, brother of Jesus. In the second half of June, especially on this day, in the 19th and early 2oth century numerous pilgrims visited Judas's grave; it is interesting that they were not only from Mezen area, but also from neighboring counties. At the beginning of the 2oth century, F.F. Lyapushkin, a peasant from the village of Ustvashka, decided to build above Judas Koneschelsky's grave a church in the name of Jude the Apostle, brother of Jesus, and establish a hermitage ${ }^{21}$ (it became widely known in the vicinity under the name Uda's hermitage and it is still known, although after it was closed and devastated only a small hut-chapel has survived there). When in 1904 requesting the Bishop of Archangels and Kholmogory Joannicius (Kazansky) to permit constructing a church, F.F. Lyapushkin informed the bishop, referring to "the preserved legend" that Judas had been a disciple of Job of Ushchel'ye (17th century), who was a monk from Solovki, the founder of the Ushchel'ye hermitage in honor of the Nativity in Mezen. After Job's martyrdom in 1628 , Judas, seeking utter solitude, allegedly left the monastery in Ushchel'ye and settled by the Popyuga river, where he lived praying to the end of his days. ${ }^{22}$ A. Grivtsev, a priest of Beloschel'ye parish, told another version of this legend with additional details: "Legend has it that in the days of Michael I of Russia, guided by providence Reverend Job, an ascetic from the famous Solovki monastery, arrived to Mezen County and brought with him four people of the brethren, including hermit Judas. <...> Reverend Job set up the Ushchel'ye hermitage and stayed there with his brethren, fasting, praying, and working on their hands to gain food. On August 5, 1628 Reverend Job suffered martyrdom - he was murdered by brigands and his brethren, being at that time with

А.В. Новиков, Лешуконье XV-ХІХ вв. История края [A.V. Novikov, Leshukon'ye in 15-19 centuries. History of the Land]. Arkhangelsk, 2003, p. 693; А.В. Новиков, Деревни Лешуконья: исторические очерки [A.V. Novikov, The Villages of Leshukon'ye: Historical Sketches]. Arkhangelsk, 2007, p. 261.

The church in the name of Jude the Apostle was built at F.F. Lyapushkin's expense in 1914, Jude's hermitage was officially opened at that time. On the history of the hermitage see: А. В. Новиков, Лешуконье XV-хIX вв., pp. 175-195; А.В. Новиков, Лешуконские храмы: очерки истории церквей, часовен, монастырей, пустынь и скитов на территории средней Мезени [A.V. Novikov, The Temples of Leshukon'ye: Essays on the History of Churches, Chapels, Monasteries, and Sketes in the Territory of Middle Mezen]. Arkhangelsk, 2015, pp. 192-222. 
him, including hermit Judas, escaped from the brigands into the dark woods and stopped by a small river named Popyuga, where they built a still existing chapel and a cell for themselves with four sections, but at present only the remains have survived. Several years later hermit Judas died; the brethren buried him and moved to the other monasteries, therefore the area is called to this day that of Judas's". ${ }^{23}$ Thus, the time when Judas lived was put in this "legend" 100150 years back (compared to the files of Mezen courts), and the devotee turned from an Old Believer into an Orthodox monk, living before Patriarch Nikon's church reforms.

However, this version was not widespread in Mezen either. In 1904 the priest of Tsenogorskoe parish Fr. Alexander Afanasyev, who, according to A. Grivtsev, used to fall back on Judas's help ${ }^{24}$, wrote in his report to the Archangelsk Consistory: "in the parish of Beloshchel'ye, seven versts away from the village of Koneschelskaya $<\ldots . .>$ in dense forests, according to a preserved legend, some elder named Judas is supposed to have lived, and that's where he died. There's a grave, but no written documents about this have survived. No one knows who the elder Judas was, from where and when he came, and whether he really existed or not in that place". 25

A diary by Mezen peasant Grigory Yakovlevich Sitnikov ${ }^{26}$ is a valuable source for the study of the veneration of Judas in the second half of the 19th century. It is housed in the Institute of Russian Literature (the Pushkin House) RAS, in the Mezen collection of manuscripts, Archives named after V.I. Malyshev. ${ }^{27}$ As a rule, records open with a precise indication of the date and chronologically cover the years between 1891 and 1909. Unlike some other peasants' dairies, ${ }^{28} \mathrm{G}$. Ya. Sitnikov's manuscript doesn't contain socioeconomic information, facts of civil history, household instructions or descriptions of the rural

23 А. Гривцев, “Белощельский приход Мезенского уезда", pp. 64-65.

24 Seе: А. Гривцев, “Белощельский приход Мезенского уезда”, p. 65.

25 Cit. ех: А. В. Новиков, Лешуконские храмы, р. 202.

26 G. Ya. Sitnikov was born in 1859 in the village of Verkhny Berezhnik, Ushchelskoe parish of Mezen county. In 1899 he became an Old Believer, Belokrinitskaya Hierarchy, in 1901 he was appointed as Old Believer priest, ministering in the village of Semzha, which in early 2oth century was the center of the Mezen Old Believers-Popovtsy. He died after 1926. See: Н.А. Окладников, Поборники древлего благочестия [N.A. Okladnikov, The Advocates of the Old Piety]. Arkhangelsk, 2012, pp. 197-208; А.В. Пигин, “Крестьянские дневники ХIX - XX вв. как источники", pp. 278-285.

27 This small-size manuscript ( 96 sheets) was found in Mezen at the time of 1967 expedition. The manuscript's index number in the Mezen manuscript collection is 151 .

28 About peasants' diaries and other memoirs stored in the Pushkin House see: Г.В. Mapкелов, “Крестьянские архивы в ДревлехранилищеПушкинского Дома” [G.V. Markelov, "Peasants' Files in the Pushkin House Archives"], in: Труды Отдела древнерусской литературы, отв. ред. О.В. Творогов [Works of Department of Old Russian Literature at IRLI, 
way of life. The author is more interested in spiritual matters; seeking to note miraculous and divine phenomena in everyday life, he writes down miracles performed by Judas Koneschelsky and Job Ushchelsky, ${ }^{29}$ and describes his own visionary experience. Moreover, the diary mentions numerous names of Mezen villages, dozens of names of local residents, and representatives of the local clergy. The diary depicts very vividly the religious life of Leshchukon'ye - the middle Mezen - in the late 19th and early 20 th centuries.

G. Ya. Sitnikov's diary lists about 20 records of Judas Koneschelsky's miracles dating from the 189os. It is noteworthy, that the local resident G. Ya. Sitnikov also did not know any biographical information about Judas. Referring to oldtimers of the village of Koneschel'ye, he stated only that Judas originated from Pinezhsky County, but this is not verified by documentary sources. ${ }^{30}$

Judas Koneschelsky's miracles, recorded by G. Ya. Sitnikov, indicate that at the end of the 19th century this saint was perceived as the patron saint of domestic animals. Leshchukon'ye residents used to turn to Judas in case of loss or illness of livestock, to take vows to place a candle over his grave, to bake "korovashki" (small loafs of bread) for the poor, to commemorate Judas, and to bring to his chapel a kerchief, an image of a lost animal, etc. In one of the miracles Judas warns a peasant woman that livestock mortality ("uskot'ye") on her homestead is caused by disrespectful attitude towards holidays (simple country folk perceived working on fast days and holidays as big sin).

The loss of livestock and its search is a very typical situation from peasant life, especially in Northern Russian villages. Because of shortage of arable land people grazed livestock mainly in the forests, enclosing the space with fallen trees or choosing areas that would be difficult for livestock to leave. Still animals often went beyond the fenced territory. On this occasion peasants developed a large arsenal of tools, both practical and magical. In the Russian North a belief was widespread that shepherds were able to enter into an agreement with a wood-sprite and herd, without watching animals, but by using sorcery. ${ }^{31}$

ed. by O.V. Tvorogov]. St. Petersburg, 1993, vol. 46, pp. 493-502. On p. $5^{00}$ there's a brief description of Sitnikov's diary.

29 About Job Ushchelsky's miracles described in G. Ya. Sitnikov's diary see: А.В. Пигин, “Чудеса Иова Ущельского (из дневника мезенского крестьянина рубежа XIX-ХX вв.) " [A.V. Pigin, "Miracles by Job Ushchelsky (From the Mezen Peasant's Diary at the Turn of 19th-2oth Centuries"], in:Живая старина [The Living Antiquity], 2016, Nr 4, pp. 2-6.

Seе: А. В. Новиков, Ущельский монастырь, pp. 168-169.

31 Seе: А.Б. Мороз, "Севернорусские пастушеские отпуска и магия первого выгона скота у славян” [A.B. Moroz, "Northern Russian Shepherds' Charms and the Magic of the First Pasturing in Slavic Culture"], in: Восточнославянский этнолингвистический сборник, под ред. С.М. Толстой [Eastern Slavic Ethnolinguistic Collection, ed. by S.M. Tolstaya]. Moscow, 2001, pp. 232-258. 
Using magical means did not call off requesting locally venerable saints and miraculous icons to make disappeared livestock come back. The function of the "livestock helper" was attributed in the North, for example, to Macarius of Unzha, venerated in Hergozero Monastery, Kargopol, and Pachomius of Kena, the Kargopol Miracle Worker. Northern Russian hand-written tales (17-18th centuries) about these saints also include stories about lost and healed animals. ${ }^{32}$ Although we don't have direct evidence, it can be assumed that the veneration of Judas Koneschelsky as an assistant in cases when livestock got lost began to shape as early as 18th century: according to investigatory files of the turn of the 18th-19th centuries, the local peasants buried a dead horse next to Judas's grave.

As noted above, Judas's Old Believer origin was gradually forgotten in Mezen. Nevertheless, G. Ya. Sitnikov's diary retained some Old Believer signs of Judas's worship. In one of the miracles, recorded by G. Ya. Sitnikov, Judas asks the woman of the house for warm water in order to cure a sick bull with its help. The woman is in a hurry to heat a samovar, but Judas stops her: "It's improper to use the samovar. The samovar is empty ("pustodom"). The word "pustodom" (literally "empty house") in the Russian North vernacular has negative connotations: it could mean a shallow, vacuous person, a bad householder, and also a samovar. ${ }^{33}$ The rejection of samovar (as well as tea drinking) as a novelty that emerged in Russian lifestyle only in the 18th century is highly characteristic of the Old Believers. In the Old Believers' writings of the 18th and 19th centuries samovar is referred to as the "brass serpent", "satanic altar" and "hell's womb". ${ }^{34}$

32 Seе: А.В. Пигин, “Литературные сочинения о преподобном Пахомии Кенском, Каргопольском чудотворце” [A.V. Pigin, "Literary Compositions about Venerable Pachomius of Kena, Kargopol Miracle Worker"], in: Вестник церковной истории [Bulletin of Ecclesiastic History]. 2009, Nr 1-2 (13-14), pp. 100-120; А.В. Пигин, “Сказание о иконе Макария Желтоводского и Унженского в Хергозерском монастыре Каргопольского уезда" [A.V. Pigin, "Tale about the Icon of Macarius of the Yellow Water Lake and the Unzha in Hergozero Monastery, Kargopol County"], in: Русская агиография: Исследования. Материалы. Публикации, отв. ред. Т.Р. Руди, С.А. Семячко [Russian Hagiography: Studies. Materials. Publications, ed. by T.R. Rudi, S.A. Semyachko]. St. Petersburg, 2011, vol. 2, pp. 76-111.

33 Словарь русских народных говоров, гл. редактор Ф.П. Сороколетов [Dictionary of Russian Folk Dialects, ed. by F.P. Sorokoletov]. St. Petersburg, 1999, iss. 33, p. 145; И.М. Дуров, Словарь живого поморского языка в его бытовом и этнографическом применении [I.M. Durov, The Dictionary of the Pomors' Living Language in its Everyday and Ethnographical Use]. Petrozavodsk, 2011, p. 349.

34 Seе: А.В. Пигин, "Сочинения о чае и самоваре в старообрядческой письменности XVIII-XX вв." [A.V. Pigin, "Works about Tea and Samovar in the Old Believers' Writings 
The cult of the non-canonized saint Judas Koneschelsky, about whom nothing is known for certain except his name, was, in fact, on the borderline between peasant magic and ecclesiastical piety. There is good reason why the local clergy's attitude to the popular worship of Judas was very controversial. For example, G. Ya. Sitnikov tells how priest Evgraf Kalinnikov from the village of Koynas made attempts to ruin Judas's chapel. Father Evgraf got permission from the "spiritual authorities" to destroy the chapel. But when his assistants went to do it, Evgraf became blind, but then he was forgiven and healed only after he had made a vow not to devastate Judas's chapel. ${ }^{35}$ Additionally, among those requesting help from Judas in connection with lost animals, G. Ya. Sitnikov names the local priest Fr. Alexey.

The perception of Judas Koneschelsky mainly as the saint patron of animals is also reflected in records made in 1910 - 1920s. For instance, the priest A. Grivtsev, in a note dating 1911, mentions the search for missing livestock as the only situation when Judas is asked for help. Although he remarks that this situation is "an example", one may think that he chooses the most typical example (wool as an oblation to the chapel he also calls "an example"). ${ }^{36}$ A.I. Nikiforov's observations dating 1920 are entirely consistent with this note: "Judas Tropinich does help. Just promise to visit him and drink some water from a birch bark dipper, light a candle, and ring a bell; then every herd will definitely return, no matter how far and where it has gone". ${ }^{37}$

The veneration of Judas Koneschelsky has been preserved in the North up to the present, and not only in Leshukon'ye. In 2011 a prayer requesting Judas was recorded in Ust-Tsilma. ${ }^{38}$ People still come to Judas's hermitage to pray and ask for help, they leave in the chapel votive offerings: clothes and towels, as well as candles and notebooks containing different wishes. ${ }^{39}$ Besides Judas,

between the 18th and 2oth Centuries"], in: Живая старина [The Living Antiquity], 2014, $\mathrm{Nr}$ 4, pp. 34-37.

35 Evgraf Kalinnikov was a priest at the church of Saint Nicholas, the Wonderworker, Koynas parish between 1846 and 1860, see: Краткое историческое описание приходов и иерквей Архангельской епархии [Brief Historical Description of Parishes and Churches in the Diocese of Archangelsk]. Arkhangelsk, 1895, iss. 2, p. 347. Thus, this story relates to the middle of the 19th century and it was recorded by G. Ya. Sitnikov as remembered by the locals.

36 А. Гривцев, “Белощельский приход Мезенского уезда”, p. 65.

37 Сказки. Легенды. Былички. Детский Фольклор, p. 595.

38 “«Явле́нная Богородица» в деревне Нонбург (Республика Коми)", публикация Т.С. Каневой и Д.И. Шомысова; предисловие Т.С. Каневой [“The Appearance of the Blessed Virgin" in the Village of Nonburg (the Republic of Komi), publication by T.S. Kaneva and D.I. Shomysov; foreword by T.S. Kaneva], in: Живая старина [The Living Antiquity], 2015, Nr 4, pp. 51-53.

Seе: А. Балакин, А. Поспелова, “Поездка к святым местам Помезенья”, pp. 172-174. 
his "spirituals brothers" Jacob the Burned and Onika (Joannicius) are venerated, but G. Ya. Sitnikov's diary doesn't contain information about them. Jacob's grave is located near the village of Beloshchel'ye, that of Onika is in the upper reaches of the Mezen, not far from the village of Lat'yuga (Udorsky District, the Republic of Komi); chapels were constructed over these graves as well.

Close to the village of Vozhgora, over Ivan's mountain, about $80 \mathrm{~km}$ away from Judas's hermitage, on a woody hill is situated another ritual complex associated with the name of Judas Koneschelsky. It includes a wayside cross with several icons and votive offerings (mainly kerchiefs) hanging on it, some nearby trees (they are also decorated with votive offerings - clothing items with stitched crosses and ribbons), an old rotten cross which (as it is also done with gravestone crosses) hasn't been carried away, but remains leaning against a tree, and, finally, a canopy over the table and benches where people have food while visiting the place. The locals call this wayside cross "the cross of Uda and Onika" or just "Uda and Onika". According to the local ethnographer A.V. Novikov, the cross was erected about ten years ago by three residents of Vozhgora - R.M. Lyapunov, A.M. and S.V. Leshukov. But it is already the third cross; the first one "was erected by the resident of Vozhgora Semen Mikhailovich Lyapunov in 1921 (or 1922) as a sign of his release from captivity. At the very beginning of the First World War he had been captured and lived in Germany as a prisoner for seven years. Presumably, he had prayed to his local patron saints so that they would help him return home. In his family he had been given up for dead. However, his country villagers are not sure that cross was the first one to be erected". ${ }^{40}$ Trinity Sunday is considered the day of the veneration of the cross. On this day a lot of people visit the cross. The rest of time the number of visitors is small - only those who are in need or passersby on their way to the forest. People stop by the cross, pray to Judas and Onika, leave clothes taken off from a sick part of the body, and hang ribbons on the trees. The cross is put up on the spot, where (as legend says) Judas and Onika parted and each of them went his own way.

In the course of constructing such motivational narratives (cross as a point of separation) several explanations are employed.41

$40 \quad$ From A.V. Novikov's letter to A.V. Pigin dated 17 November 2018.

41 Below the authors employ material from expeditions undertaken by the Russian State University for the Humanities (Moscow) to the village of Vozhgora (2014) and by Saint Petersburg State University to Vozhgora, Tsenogora, Selishche, Beloshchel'ye villages (2009-2010, 2016). The material is housed in the Archive of Folklore Studies Laboratory at the Russian State University for the Humanities and in the Propp Center for the Faculty of Philology at Saint Petersburg State University. 
1. Elevation to the sacred realm. Judas and Onika are declared saints. This is the most distinct and universal model. Such factors as the existence of the cross and cult, as well as bringing votive objects and requesting help, inevitably lead to conceiving of these characters as saints, who have traveled through a particular area, stopped by at the revered place, and remained etched in local memory. The model of holiness does not always agree with the canonical one, and the saint's status is often explained through related concepts: "sinless", "helped people", "old man", "died long ago", "hermit", "built himself a cell/cha$\mathrm{pel} / \mathrm{church}$ ", etc.

2. Attributing local history to a folklore version. Among existing legends in Leshukon'ye, texts about the Chudes are widespread. The Chudes are mythical people who originally lived in this area (stories about the folklore Chudes don't have direct relation to the historical Chudes), fought against the ancestors of the present day settlers, and were killed either by the latter or as a result of fighting between themselves. ${ }^{42}$ Specifically in the village of Vozhgora and neighboring villages plotlines about the Chudes are linked mainly to a toponymic legend, which explains the origin of the toponym Chuchepala (here "chuch (meaning Chude-A.M., A.P.) pala" - fell, died"). According to the version of an informant, Judas and Onika lived at the time of these "particular" Chudes "and fought".

3. Interpreting a character's name through correlation with a more widely known character of the same name. Fame does not imply special knowledge about the characters, on the contrary, the key point here is not knowing the facts, circumstances or storylines, but only the prominence of the name itself or a cliché associated with this name. This situation reflects the tendency in traditional culture to unite all characters under a single image; this phenomenon was already noted by H. Delehaye..$^{43}$ Identifying Judas Koneschelsky with the most famous Judas, apostle who betrayed Jesus, sometimes occurs, however, for obvious reasons, appears rather flabby and a bit of a stretch. It should be interpreted as an oddity or misunderstanding between the collector and informant. The name of the second character, Onika, is associated with that of Anika the Warrior; this is recorded in fieldwork files and in literature on local lore. ${ }^{44}$ Anika the Warrior is a character of spiritual verse, lubok (popular print),

Seе: Н.В. Дранникова, Р. Ларсен, “Образ «чуди» в фольклоре народов Европейского Севера" [N.V. Drannikova, R. Larsen, "The Image of the "Chudes" in the Folklore of the European North"], in: Чудь в устной традииии Архангельского Севера, под ред. H.В. Дранниковой [The Chudes in the Oral Tradition of the Archangelsk North, ed. by N.V. Drannikova]. Arkhangelsk, 2008, pp. 19-47.

43 H. Delehaye, The Legends of the Saints. New York, 1962, p. 17.

44 Seе: А.В. Новиков, Лешуконье XV-ХIX вв., р. 178. 
and the popular drama "King Maximilian". However, in Onika's of Mezen case, the direct source is the idiom "Anika the Warrior" itself, which exists in Russian language without any reference to the storyline of the spiritual verse, drama or lubok, and is used playfully meaning a person who looks either needlessly or excessively menacing and belligerent: "The one who brags about his strength, a lively, perky, person (in the vernacular)". 45 In the texts of people, who have such an association, we find direct identification of the local Onika with the idiomatic Anika the Warrior: "Judah was a scribe and mathematician. Everyone knows, Onika is a warrior". 46

Field study records made in the early 21st century enable to trace occurred changes regarding the subjects of appeals to Judas, in comparison with the situation that was one hundred years ago. Requests for assistance in finding lost livestock are still relevant, but, first, these texts never mention the custom to bake small loafs of bread ("korovashki") and to give them out to poor people so that they would pray to Judas; second, these requests don't prevail over others. This is probably partly due to the fact, that since the last third of the 2oth century the danger of losing livestock has ceased to be one of the most common fears of a Northern Russian peasant: the amount of livestock has significantly reduced, forest grazing has discontinued, and village cows, now small in number, graze within sight. The subjects of appeals to Judas and Onika have recently expanded to almost universal. In the minds of the locals, Judas is a saint and they appeal to him as to a local (their own, personal) saint whenever possible. His name is the first one that comes to mind when there is danger.

A driver told how he was driving along a frozen river in spring. The lower part of the wheels went under the water, and only after the driver had asked Judas for help, "some force" lifted the wheels and five minutes later the car was already on the shore. Judas is also asked for health, safe travel, and "success"; praying to the elder even helps to buy an apartment. The range of subjects of appeal to Judas is gradually expanding and the rural shrines become a means of fulfilling wishes. The character of the place as the "spot where wishes are fulfilled" is also emphasized by, not quite typical and even, apparently, new for the rural shrines, decorating trees with ribbons in parallel with still existing practice of leaving clothing items taken off from a sick part of the

45 Словарь современного русского литературного языка, под ред. В.И. Чернышева [Dictionary of Contemporary Russian Literary Language, ed. by V.I. Chernyshev]. Leningrad, 1950, vol. 1, p. 142.

46 Валерий, село Троицко-Печорск, "Шепот звезд или голос Бога" [Valery, TroitskoPechersk village, "Whisper of Stars or God's Voice"], in: Вера. Христианская газета Севера России [Faith. Christian Newspaper of the Russian North], 2001, Nr 423, iss. $1<$ http:// www.rusvera.mrezha.ru/423/7.htm>. 
body. Obviously, such "modernization" is tied both to the changing conditions of rural living and, despite the inaccessibility of the place, the significant number of visiting urban dwellers (including those who were born in villages).

Considering the case of Judas Koneschelsky's cult and related texts, we see how folk hagiography is shaped and functions. After the hermit's death, his place of residence and a number of natural objects around undergo sanctification. Later, by analogy, other sacred places emerge in villages that are more distant from the hermitage, or nearby these villages, to be exact, since local shrines are usually located within walking distance of housing. The specific character of the local nature and ways of housekeeping have determined the saint's basic function - helping to find missing livestock in the forest. This role has been assigned to him and confirmed by the miracles, described in G. Ya. Sitnikov's diary. The elder is correlated with other saints of the same name, which testifies to the universalization, typical of folk hagiography, as well as a tendency to consolidate all characters of the same name into a single one. Moreover, the life of Judas fits into the context of the local version of folk (quasi)-history. He has become a sacred and, interestingly enough, historical character, whose participation in significant events of the past further raises his status.

Modern living conditions of society have changed the nature of worship. Judas has become a "universal" helper, and his "specialization" in helping to find missing livestock has taken a back seat due to radical changes in the household activities of the local residents. Nevertheless, the veneration itself has been preserved. In villages narratives devoted to Judas are transmitted, motivating the necessity of the cult. 